Volume $\mathbf{4 5}$

Number 4

November 2011

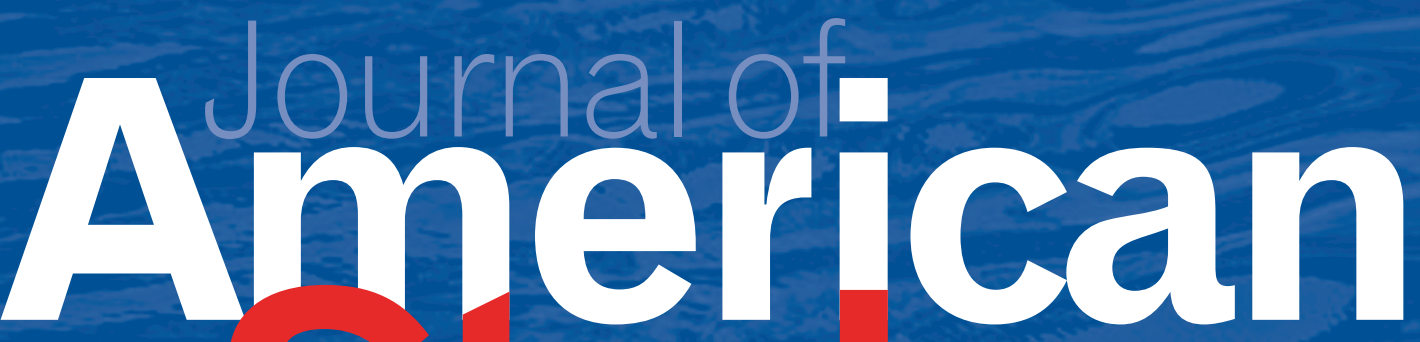

Special issue

10 Years After 9/11

CAMBRIDGE

UNIVERSITY PRESS 


\author{
Scott Lucas (Editor) \\ University of Birmingham
}

Celeste-Marie Bernier (AssociateEditor)

University of Nottingham

Bevan Sewell (Associate Editor)

University of Nottingham

Mike Dunn (Editorial Assistant)

University of Nottingham

Hannah Durkin (Editorial Assistant)

University of Nottingham

\section{Janet Beer}

Oxford Brookes University

Ian Bell

Keele University

Richard Crockatt

University of EastAnglia

Susan Currell

University of Sussex

Jane Dailey

University of Chicago

Wai Chee Dimock

Yale University

\section{Shelley Fisher Fishkin}

Stanford University

Martin Halliwell

University of Leicester

\section{Paul Giles}

University of Sydney

Jo Gill

University of Exeter

George Lewis

University of Leicester

Judie Newman

University of Nottingham

Jacques Pothier

University of Versailles

Simon Newman

University of Glasgow

Giles Scott-Smith

Roosevelt Study Center/

Roosevelt Academy

\section{David Seed}

University of Liverpool

Carol Smith

University of Winchester

\section{Theresa Saxon}

University of Central Lancashire

Marjorie Spruill

University of South Carolina

Brian Ward

University of Manchester

\section{American \\ Studies}

\section{Subscriptions}

Journal of American Studies is published four times a year in February, May, August and November. The subscription price (excluding VAT), which includes postage, of Volume 45, 20II, is $£_{213}$ (USA, Canada and Mexico US \$356), for institutions print and electronic, institutions electronic only $£_{19 I} / \$ 332$; individual rates are available on application to the publisher. Single parts are available at $£_{5} 6$ net (USA, Canada and Mexico \$98) each. Orders, which must be accompanied by payment, may be sent to a bookseller, subscription agent or to the publishers: Cambridge University Press, The Edinburgh Building, Shaftesbury Road, Cambridge $\mathrm{CB}_{2} 8 \mathrm{RU}$ or in the USA, Canada and Mexico to Cambridge University Press, The Journals Fulfillment Department, Ioo Brook Hill Drive, West Nyack, New York 10994-2133. EU subscribers (outside the UK) who are not registered for VAT should add VAT at their country's rate. VAT registered subscribers should provide their VAT registration number. Japanese prices for institutions are available from Kinokuniya Company Ltd, P.O. Box 55, Chitose, Tokyo 156, Japan. Prices include delivery by air. Copies of the Journal for subscribers in the USA, Canada and Mexico are sent by air to New York to arrive with minimum delay.

\section{Copying}

This journal is registered with the Copyright Clearance Center, 222 Rosewood Drive, Danvers, MA OI923. Organizations in the USA who are also registered with CCC may therefore copy material (beyond the limits permitted by sections I07 and I08 of US Copyright law) subject to payment to CCC of the per copy fee of \$12.00. This consent does not extend to multiple copying for promotional or commercial purposes. Code 002I-8758/201I/BAAS-OOOI \$I2.00. ISI Tear Sheet Service, 350I Market Street, Philadelphia, Pennsylvania 19104, USA is authorized to supply single copies of separate articles for private use only.

Organizations authorized by the Copyright Licensing Agency may also copy material subject to the usual conditions. For allother use, permission should be sought from Cambridge or the American Branch of Cambridge University Press.

Claims for missing issues will be considered only if made immediately upon receipt of the subsequent issue.

\section{Internet access}

This journal is included in the Cambridge Journals Online service which can be found at http://journals.cambridge.org. For further information on other Press titles access http://www.cambridge.org

\section{Book Reviews}

Editorial correspondence relating to book reviews should be sent to the Journal of American Studies, School of American and Canadian Studies, University of Nottingham, Nottingham NG7 2RD, UK, jas@nottingham.ac.uk.

The British Association for American Studies (BAAS) was founded in 1955 to promote the study of the United States within the United Kingdom. Members of BAAS may subscribe to Journal of American

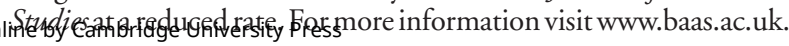




\section{Contents}

Editorial

iii

\section{Articles}

Beyond the Ends of the Earth: Donald Rumsfeld, the Mantra of

Progress, and an Outer-Space View of America's War on Terror 643

Lloyd Gardner and Bevan Sewell

Bush's "Useful Idiots": 9/1 I, the Liberal Hawks and the Cooption of the "War on Terror"

Maria Ryan

The "Global War on Terror," Identity, and Changing Perceptions :

Iraqi Responses to America's War in Iraq

Jenna Pitchford

"How Do We Write about This?" The Domestic and the Global in the Post-9/ I I Novel

Catherine Morley

Compromised Critique: A Meta-critical Analysis of American Studies after 9/I I

LUCY BOND

Deterritorializing the "Homeland" in American Studies and American Fiction after $9 /$ i I

Rick CROWNSHAw

Politics and Poetics of Fear after 9/ I I : Claudia Rankine's Don't

Let Me Be Lonely

EMma KimberLeY

9/ I I Digitally Remastered? Internet Archives, Vernacular Memories

LEE JARVIS and WhereWereYou.org

Regarding the Pain of Others: Scenarios of Obligation in Post-9/ I I US Cinema

Guy Westwell

September I I as Heist

Hamilton CARroll

\section{Electronic Content}

\section{Falling Man Round Table}

The Ascent of the Falling Man: Establishing a Picture's Iconicity

Rob Kroes

Against Iconicity: Photography and 9/ i I : A Response to Rob Kroes

Miles Orvell 
Falling Man's Descent into Meaning: A Response to Rob Kroes

Alan Nadel

\section{Conference Report}

"Russian/Soviet Studies in the United States, American Studies in Russia: Mutual Representations," I6-I 7 February 20 I I, Russian State University for the Humanities (RSUH), Moscow

DAVID Ayers

\section{Exclusive Online Reviews www.journals.cambridge.org/ams}

The following reviews are freely available in the online version of this issue at www.journals. cambridge.org/ams.

Carrie Pitzulo, Bachelors and Bunnies: The Sexual Politics of Playboy

Samuel Otter, Philadelphia Stories: America's Literature of Race and Freedom

Steven Lubet, Fugitive Justice: Runaways, Rescuers, and Slavery on Trial

Donald Stoker, The Grand Design: Strategy and the U.S. Civil War

Joe B. Fulton, The Reconstruction of Marke Twain: How a Confederate Bushwhacker Became the Lincoln of Our Literature

Bernd Herzogenrath, An American Body/Politic: A Deleurian Approach

Stuart Burrows, A Familiar Strangeness: American Fiction and the Language of Photography, 1839-1945

Molly Rogers, Delia's Tears: Race, Science, and Photography in Nineteenth-Century America

Mark Goble, Beautiful Circuits: Modernism and the Mediated Life

Lisa K. Perdigao, From Modernist Entombment to Postmodernist Exhumation: Dead Bodies in Twentieth Century American Fiction

Jennifer Rae Greeson, Our South: Geographic Fantasy and the Rise of National Literature

Stephen G. Rabe, Jobn F. Kennedy: World Leader

Donna Jean Murch, Living for the City: Migration, Education, and the Rise of the Black Panther Party in Oakland, California
Brian Ireland, The US Military in Hawai $i$ : Colonialism, Memory, and Resistance

Jesús Velasco, Neoconservatives in U.S. Foreign Policy under Ronald Reagan and George W. Bush: Voices bebind the Throne

Xiaojian Zhao, The New Chinese America: Class, Economy, and Social Hierarchy

James Peacock, Understanding Paul Auster

Tom Theobald, Existentialism and Baseball: The French Philosophical Roots of Paul Auster

Andreas Hau, The Implosion of Negativity: The Poetry and Early Prose of Paul Auster

David Stirrup, Louise Erdrich

Philip C. Kolin (ed.), Suzan-Lori Parks: Essays on the Plays and Other Works

Michael L. Ondaatje, Black Conservative Intellectuals in Modern America

David B. Magleby and Anthony Corrado (eds.), Financing the 2008 Election

James Der Derian, David Udris and Michael Udris, Human Terrain: War Becomes Academic

Anthony B. Pinn, Caroline F. Levander, and Michael O. Emerson (eds.), Teaching and Studying the Americas: Cultural Influences from Colonialism to the Present

Anthony B. Pinn, Caroline F. Levander, and Michael O. Emerson (eds.), Teaching and Studying the Americas: Cultural Influences from Colonialism to the Present

Frank Kelleter and Daniel Stein (eds.), American Studies as Media Studies 